\begin{tabular}{cc|c}
\hline Tar. Bil. Der. & Journal of Agricultural Sciences \\
& $\begin{array}{c}\text { Dergi web sayfası: } \\
\text { www.agri.ankara.edu.tr/dergi }\end{array}$ & Journal homepage: \\
& www.agri.ankara.edu.tr/journal
\end{tabular}

\title{
Effects of Soil Application of Neem on Some Biological Characteristics of Myzus persicae (Sulzer) (Hemiptera: Aphididae)
}

\author{
Ali Kemal BİRGÜCÜ ${ }^{a}$, Şenay ÖZGER ${ }^{\text {a }}$, Daniel POHL ${ }^{\text {a, İsmail KARACA }}{ }^{\text {a }}$

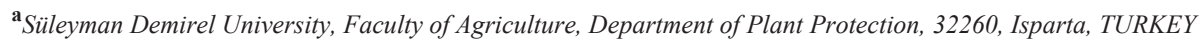

\section{ARTICLE INFO}

Research Article

DOI: 10.15832 /ankutbd. 446452

Corresponding Author: Ali Kemal BİRGÜCÜ, E-mail: alibirgucu@sdu.edu.tr, Tel: +90 (246) 2118169

Received: 06 July 2015, Received in Revised Form: 02 November 2017, Accepted: 14 November 2017

\begin{abstract}
The study investigated the effect of soil application of neem at different concentrations on lifetable parameters of Myzus persicae (Sulzer) (Hemiptera: Aphididae). After pepper seedlings were transplanted to pots of $1.5 \mathrm{~L}$, the pepper plants had been divided into five different groups to be watered with only irrigation water (as control) and irrigation water containing 250, 500, 750 and $1000 \mathrm{mg} \mathrm{L}^{-1}$ of neem.

Based on the results, intrinsic rate of increase $\left(\mathrm{r}_{\mathrm{m}}\right)$, net production rate $\left(\mathrm{R}_{0}\right)$ and mean generation time $\left(\mathrm{T}_{0}\right)$ ranged from 0.039 to 0.352 female/female/day, 1.700 to 57.295 female/female and 11.503 to 15.086 days respectively. Doubling time $\left(\mathrm{T}_{2}\right)$ and finite rate of increment $(\lambda)$ ranged from 1.970 to 17.915 days and 1.039 to 1.422 individual/female/day, respectively. Consequently, the effect of neem on biological characters of the pest was increased in response to the increase in neem concentration applied systemically through plant root.
\end{abstract}

Keywords: Pepper; Neem; Green peach aphid; Lifetable; Weibull; Enkegaard

\section{Topraktan Neem Uygulamasının Myzus persicae (Sulzer) (Hemiptera: Aphididae)'nin Bazı Biyolojik Özellikleri Üzerine Etkisi}

\section{ESER BILLGISI}

Araştırma Makalesi

Sorumlu Yazar: Ali Kemal BİRGÜCÜ, E-posta: alibirgucu@sdu.edu.tr, Tel: +90 (246) 2118169

Geliş Tarihi: 06 Temmuz 2015, Düzeltmelerin Gelişi: 02 Kasım 2017, Kabul: 14 Kasım 2017

\section{ÖZET}

$\mathrm{Bu}$ çalışmada biber bitkilerinin kök bölgesine uygulanmış neem ekstraktının Myzus persicae (Sulzer) (Hemiptera: Aphididae)'nin yaşam çizelgesi parametreleri üzerine etkileri incelenmiştir. Biber fideleri 1.5 L'lik saksılara şaşırtıldıktan sonra, 250, 500, 750 ve $1000 \mathrm{mg} \mathrm{L}^{-1}$ neem içeren sulama suları ile sulanmak üzere dört farklı gruba ayrılmıştır.

Yapılan analiz sonuçlarına göre kalıtsal üreme yeteneği $\left(\mathrm{r}_{\mathrm{m}}\right)$, net üreme gücü $\left(\mathrm{R}_{0}\right)$ ve ortalama döl süresi $\left(\mathrm{T}_{0}\right)$ değerleri sırasıyla 0,039 ile 0,352 dişi/dişi/gün, 1,700 ile 57,295 dişi/dişi ve 11,503 ile 15,086 gün arasında değişiklik göstermiştir. 
Popülasyonun ikiye katlanma süresi $\left(T_{2}\right)$ ve üreme gücü sınırı $(\lambda)$ değerleri ise sırasıyla 1,970 ile 17,915 gün ve 1,039 ile 1,422 birey/dişi/gün arasında değişmiştir. Sonuç olarak kökten uygulanan neem konsantrasyonu arttıkça, neemin zararlının biyolojik özellikleri üzerine etkisi de artmıştır.

Anahtar Kelimeler: Biber; Neem; Yeşil şeftali yaprakbiti; Yaşam çizelgesi; Weibull; Enkegaard

(C) Ankara Üniversitesi Ziraat Fakültesi

\section{Introduction}

The green peach aphid, Myzus persicae (Sulzer) (Hemiptera: Aphididae) which is a polyphagous pest has more than 400 host plants (Cloyd \& Sadof 1998). This pest causes damage on different stone fruit species, especially peach, and on many vegetable species such as tomatoes, pepper, potato, cabbage, pumpkin, and okra. It also feeds on lots of weeds as well (Uygun et al 2013).

M. persicae causes curling downwardly of the end portions of leaves, deceleration of the host plat growth and dark-colored sooty mold, known as fumagine, by honeydew secreted during feeding on the host plant. It is also know that this insect is a vector of more than 86 plant virus diseases (Cloquemin et al 1990).

Chemical control is primarily preferred in controlling the pest because of its easy application and rapid responding. These chemicals have many adverse effects on human health and environment, which led producers to use alternative control methods (Bajwa \& Ahmad 2012). In this context, one of the alternative control methods against pests is also the use of plant-based preparations.

Natural products with pesticidal effects have been in the control of weeds, plant diseases and pests since ancient times (Isman 1997; Ujváry 2001). One of these plant-based insecticides is the compound derived from various parts of Azadirachta indica A. Juss (Meliaceae), also known as neem.

Neem-containing products are effective against more than 400 species of insects. Neem has antifeedant and lethal effects, in addition to its effect on metamorphosis of insects. Also, it can affect eggs and fecundity of the pests (Isman 1997; Waghmare et al 2007). Neem-containing products may have slightly phytotoxic effect on some plants (Walter 1999; Girish \& Shankara Bhat 2008; Saha et al 2011). It is known that more than 550 pest species have become resistant to synthetic pesticides. The control of these pests may be possible with neem-containing products (Ascher 1993; Bajwa \& Ahmad 2012).

This study examined the effect of soil application of neem at 250, 500, 750 and $1000 \mathrm{mg} \mathrm{L}^{-1}$ concentrations on some biological characteristics, such as the time of development, preoviposition, oviposition, postoviposition and adult life, and the rates of survival and fecundity of $M$. persicae. Additionally, age-specific survival and fecundity rates of individuals on plants exposed to neem at different concentrations were described by the Weibull frequency distribution and the Enkegaard regression models.

\section{Material and Methods}

\subsection{Insect and plant breeding}

Pepper seedlings were transplanted to pots of 1.5 $\mathrm{L}$, containing a mixture of peat and sterilized soil in ratio of 1:1. Afterwards, the pots with pepper seedlings were divided into five different groups to be watered with only irrigation water (as control) and irrigation water containing 250, 500, 750 and $1000 \mathrm{mg} \mathrm{L}^{-1}$ of neem $\left(\mathrm{NeemAzal}^{\mathbb{1}}-\mathrm{T} / \mathrm{S}\right)$. All plant groups were simultaneously watered every 3-4 days. None of fertilizers and other pesticides was applied for the plants. When the plants reached the 5-6 cm height, three plants randomly selected from each plant groups were infected separately with 10 apterous female aphids by a fine paintbrush. The first offspring of these female aphids were the mother individuals, of which life table parameters were determined. 
The studies of insect and plant breeding were conducted in controlled climate room conditions at $25 \pm 1{ }^{\circ} \mathrm{C}$ temperature, $60 \pm 5 \%$ relative humidity and 16:8 $\mathrm{h}$ photoperiod. All plant groups exposed to neem at different concentrations were arranged in a completely randomized pot design.

\subsection{Experimental establishment}

Fifteen individuals randomly and separately selected from the first offspring born within 24 hours on each plant groups were used in the experiments on life table. Each of these 15 individuals was separately put on pepper leaves in petri dishes at the base of which located a thin damp sponge and blotting paper, using a fine paintbrush. Thus the experiment was set, so that 15 replications for each plant groups exposed to neem at different concentrations. Pepper leaves in petri dishes were renovated when considered necessary. Parameters of development time, survival rate, times of preoviposition, oviposition and postoviposition, and longevity during the experiment were observed. Also, after numbers of offspring given by adult females were recorded daily, offspring individuals were removed from the petri dishes. The experiment which continued until death of all individuals was conducted in a climate chamber at $25{ }^{\circ} \mathrm{C}$ temperature, $60 \%$ relative humidity and 16:8 h photoperiod (light:dark).

\subsection{Life table and statistical analysis}

After recording the data on daily basis, the following parameters of the age-specific life table of $M$. persicae reared on plants exposed to neem at different concentrations were calculated by using RmStat-3 (Özgökçe \& Karaca 2010).

The age-specific survival rate $\left(1_{x}\right)$ and fecundity rate $\left(\mathrm{m}_{\mathrm{x}}\right.$, offspring/female/day) which is computed by multiplying the mean number of offspring by the sexual ratio (Birch 1948),

Net reproductive rate $\left(R_{0}=\sum l_{x}, m_{x}\right)$ (female/female), i.e. the mean number of offspring which are laid by a female in her lifetime (Birch 1948),

Intrinsic rate of increase $\left(\mathrm{r}_{\mathrm{m}}\right.$, female/female/day) by taking advantage from Euler-Lotka equation $\left(\sum e^{\left(-r_{m} x\right)} l_{x} \cdot m_{x}=1\right)($ Birch 1948),

Mean generation time (day), $T_{o}=\frac{\ln R_{0}}{r_{m}}($ Birch 1948),

Gross reproduction rate, $G R R=\sum m_{x}($ Birch 1948),

Finite rate of increase (individual/female/day), $\lambda=e^{r_{m}}$ (Birch 1948),

Theoretical population-doubling time (day), $T_{2}=\frac{\ln 2}{r_{m}}$ (Kairo \& Murphy 1995),

Reproductive value (female/female), $V_{x}=\frac{\sum_{y=x}\left(e^{r_{m} \cdot y} \cdot l_{y} \cdot m_{y}\right)}{l_{x^{-}-r^{-r_{m} x}}}$ (Imura 1987)

Where; $\mathrm{x}$ is the female's age in days; $\mathrm{e}$ is Euler's number which is a mathematical constant (approximately equal to 2.71828).

Pseudo- $r_{\mathrm{mj}}$ values of the intrinsic rate of increase $\left(\mathrm{r}_{\mathrm{m}}\right)$ values computed on the data obtained from these populations, in order to be used in comparison test, were calculated according to the jackknife resampling method (Meyer et al 1986; Özgökçe \& Atlihan 2004) and then, Tukey multiple comparison test (Tukey 1949) was applied after One-Way 
ANOVA for these pseudo- $r_{m j}$ values of the intrinsic rates. Statistical analyses were performed by using IBM $^{\circledR}$ SPSS $^{\circledR}$ Statistics (Version 20.0, August 2011, SPSS Inc., Chicago, IL, USA) and MS Excel 2010 (Version 14.0) package programs.

Two-parameter Weibull distribution model was used to describe age-specific survival rate $\left(1_{x}\right)$ of individuals on plants exposed to neem at 250, 500, 750 and $1000 \mathrm{mg} \mathrm{L}^{-1}$ concentrations (Deevey 1947; Pinder et al 1978; Tingle \& Copland 1989; Wang et al 2000). The parameters of this distribution model were calculated according to the following formula:

$S_{p}(x)=e^{\left[-\left(\frac{x}{b}\right)^{c}\right]} \quad x, b, c>0$

Where; $S_{p}(x)$ is the probability of survival at $\mathrm{x}$ age; $\mathrm{x}$ is the female's age in days; $\mathrm{b}$ is a scale parameter and $\mathrm{c}$ is a shape parameter. The shape parameter of the curve belonging to the agespecific survival rate $\mathrm{c}>1, \mathrm{c}=1$ or $\mathrm{c}<1$ correspond to Deevey's (1947) type I, II or III survivorship curves, respectively (Pinder et al 1978).

Description of the age-specific fecundity rate $\left(\mathrm{m}_{\mathrm{x}}\right)$ of apterous adult females on plants exposed to neem at $250,500,750$ and $1000 \mathrm{mg} \mathrm{L}^{-1}$ concentrations was performed by Enkegaard regression model (Enkegaard 1993; Hansen et al 1999).

$F_{(x)=a \cdot x \cdot \varepsilon^{(-b x)}}$

Where; $F(x)$ is the probability of fecundity at $\mathrm{x}$ age (female/female/day); $\mathrm{x}$ is the female's age in days; $a$ and $b$ are constant parameters; e, Euler's number which is mathematical constant (approximately equal to 2.71828 ).

The parameters and the coefficients of determination $\left(\mathrm{R}^{2}\right)$ in both models were obtained using SigmaPlot ${ }^{\circledR}$ (Version 11.0, Systat Software, Inc., San Jose California, USA) package program.

\section{Results and Discussion}

\subsection{Development and adult longevity}

The durations of development and lifespan of Myzus persicae on plants exposed to 250, 500, 750 and $1000 \mathrm{mg} \mathrm{L}^{-1}$ neem concentrations are given in Table 1. According to these results, duration of all immature stages increased in response to the rise of exposure neem concentration. However, the adult lifespan decreased inversely with increasing concentrations (Table 1).

Neem increased significantly the development period of Aphis glycines (Hemiptera: Aphididae) in a study by Kraiss \& Cullen (2008) investigating the effect of neem-based insecticides on $A$. glycines and one of its predators. Silva et al (2013) studied the sublethal effects of the extracts derived from Azadirachta indica to Ceratitis capitata (Diptera: Tephritidae). The results of the study showed that the adult lifespan was decreased by the extracts. In addition, preoviposition time was not affected; however, a reduction in the number of eggs laid per day occurred.

\subsection{Age-specific survival rate}

The age-specific survival rate $\left(1_{x}\right)$, fecundity rate $\left(\mathrm{m}_{\mathrm{x}}\right)$, and reproductive value $\left(\mathrm{V}_{\mathrm{x}}\right)$ of $M$. persicae exposed to neem at different concentrations are given in Figure 1.

The individuals exposed to $250 \mathrm{mg} \mathrm{L}^{-1}$ showed higher reproductive value, such as those in the control group, compared to the individuals exposed to higher concentrations of neem. $46.7 \%$ of the individuals in the control group, $60.0 \%$ of the individuals exposed to $250 \mathrm{mg} \mathrm{L}^{-1}$ and all individuals exposed to higher concentrations of neem died up to the $30^{\text {th }}$ day. Kraiss \& Cullen (2008) suggested that the mortality rate of A. glycines nymphs exposed to neem-based insecticide reached up to $77-80 \%$ and the development time of surviving individuals was also elongated.

Di Ilio et al (1999) established 5 different experimental groups, with liquid rearing diet only (as positive control), no food (as negative control), neem only $\left(20 \mu \mathrm{L} \mathrm{mL} \mathrm{m}^{-1}\right)$, neem:food (1:1 mixture) and neem:food (2:1 mixture) researching the efficacy of neem compounds on longevity and fecundity of Ceratitis capitata adults. The study revealed that longevities of adults were 22.9 days in the positive control group, 15.9 days in the neem:food $(2: 1$ mixture) group, 15.2 days in the neem:food (1:1 
Table 1- Development duration and lifespan of Myzus persicae on plants exposed to different neem concentrations

\begin{tabular}{|c|c|c|c|}
\hline Biological stages & Concentrations & $N$ & Duration $\pm S E$ (day) \\
\hline \multirow{5}{*}{ First larval stage } & Control & 15 & $1.00 \pm 0.00 \mathrm{c}$ \\
\hline & $250 \mathrm{mg} \mathrm{L}^{-1}$ & 15 & $1.00 \pm 0.00 \mathrm{c}$ \\
\hline & $500 \mathrm{mg} \mathrm{L}^{-1}$ & 15 & $1.67 \pm 0.13 \mathrm{~b}$ \\
\hline & $750 \mathrm{mg} \mathrm{L}^{-1}$ & 15 & $1.93 \pm 0.07 \mathrm{ab}$ \\
\hline & $1000 \mathrm{mg} \mathrm{L}^{-1}$ & 15 & $2.13 \pm 0.19 \mathrm{a}$ \\
\hline \multirow{5}{*}{ Second larval stage } & Control & 15 & $1.67 \pm 0.13 \mathrm{a}$ \\
\hline & $250 \mathrm{mg} \mathrm{L}^{-1}$ & 15 & $1.73 \pm 0.12 \mathrm{a}$ \\
\hline & $500 \mathrm{mg} \mathrm{L}^{-1}$ & 15 & $1.93 \pm 0.12 \mathrm{a}$ \\
\hline & $750 \mathrm{mg} \mathrm{L}^{-1}$ & 15 & $1.87 \pm 0.10 \mathrm{a}$ \\
\hline & $1000 \mathrm{mg} \mathrm{L}^{-1}$ & 15 & $2.00 \pm 0.20 \mathrm{a}$ \\
\hline \multirow{5}{*}{ Third larval stage } & Control & 15 & $1.40 \pm 0.13 \mathrm{~b}$ \\
\hline & $250 \mathrm{mg} \mathrm{L}^{-1}$ & 15 & $1.53 \pm 0.13 \mathrm{~b}$ \\
\hline & $500 \mathrm{mg} \mathrm{L}^{-1}$ & 15 & $1.87 \pm 0.13 \mathrm{ab}$ \\
\hline & $750 \mathrm{mg} \mathrm{L}^{-1}$ & 15 & $2.00 \pm 0.10 \mathrm{ab}$ \\
\hline & $1000 \mathrm{mg} \mathrm{L}^{-1}$ & 15 & $2.33 \pm 0.28 \mathrm{a}$ \\
\hline \multirow{5}{*}{ Fourth larval stage } & Control & 15 & $1.80 \pm 0.11 \mathrm{a}$ \\
\hline & $250 \mathrm{mg} \mathrm{L}^{-1}$ & 15 & $2.07 \pm 0.21 \mathrm{a}$ \\
\hline & $500 \mathrm{mg} \mathrm{L}^{-1}$ & 15 & $2.33 \pm 0.19 \mathrm{a}$ \\
\hline & $750 \mathrm{mg} \mathrm{L}^{-1}$ & 15 & $2.27 \pm 0.21 \mathrm{a}$ \\
\hline & $1000 \mathrm{mg} \mathrm{L}^{-1}$ & 15 & $2.56 \pm 0.30 \mathrm{a}$ \\
\hline \multirow{5}{*}{ Total development time } & Control & 15 & $5.87 \pm 0.13 \mathrm{~b}$ \\
\hline & $250 \mathrm{mg} \mathrm{L}^{-1}$ & 15 & $6.33 \pm 0.23 b$ \\
\hline & $500 \mathrm{mg} \mathrm{L}^{-1}$ & 15 & $7.80 \pm 0.18 \mathrm{a}$ \\
\hline & $750 \mathrm{mg} \mathrm{L}^{-1}$ & 15 & $8.07 \pm 0.23 \mathrm{a}$ \\
\hline & $1000 \mathrm{mg} \mathrm{L}^{-1}$ & 15 & $7.53 \pm 0.50 \mathrm{a}$ \\
\hline \multirow{5}{*}{ Lifespan } & Control & 15 & $29.00 \pm 1.44 \mathrm{a}$ \\
\hline & $250 \mathrm{mg} \mathrm{L}^{-1}$ & 15 & $28.47 \pm 1.43 \mathrm{ab}$ \\
\hline & $500 \mathrm{mg} \mathrm{L}^{-1}$ & 15 & $23.27 \pm 0.94 \mathrm{bc}$ \\
\hline & $750 \mathrm{mg} \mathrm{L}^{-1}$ & 15 & $17.93 \pm 1.60 \mathrm{~cd}$ \\
\hline & $1000 \mathrm{mg} \mathrm{L}^{-1}$ & 15 & $13.44 \pm 1.07 \mathrm{~d}$ \\
\hline
\end{tabular}

*, within same biological stages, the values ( \pm standard error) means sharing a letter are not significantly different from each other (Tukey's at $\mathrm{P}<0.05$ )

mixture) group, 6.5 days in the negative control group and 4.4 days in the group where only neem $\left(20 \mu \mathrm{L} \mathrm{mL}^{-1}\right)$ was used.

Di Ilio et al (1999) has also explored the effect of $1: 1$ ratio mixtures of neem solutions at $1,5,10 \mu \mathrm{L}$ $\mathrm{mL}^{-1}$ concentrations with liquid rearing diet. In this experiment, 1:1 ratio mixture of distilled water with liquid rearing diet was used as control. According to the data obtained from this experiment, the longevities of adults were 24.7 days in the control group, 20.1 days in the group used $1 \mu \mathrm{L}$ neem, 9.4 days in the group used $5 \mu \mathrm{L}$ neem and 4.0 days in the group used $10 \mu \mathrm{L}$ neem.

The best survival curves for apterous adult females on plants exposed to neem at different concentrations were described by the two-parameter Weibull distribution according to the age-specific survival rates $\left(1_{x}\right)$ (Figure 2$)$. 


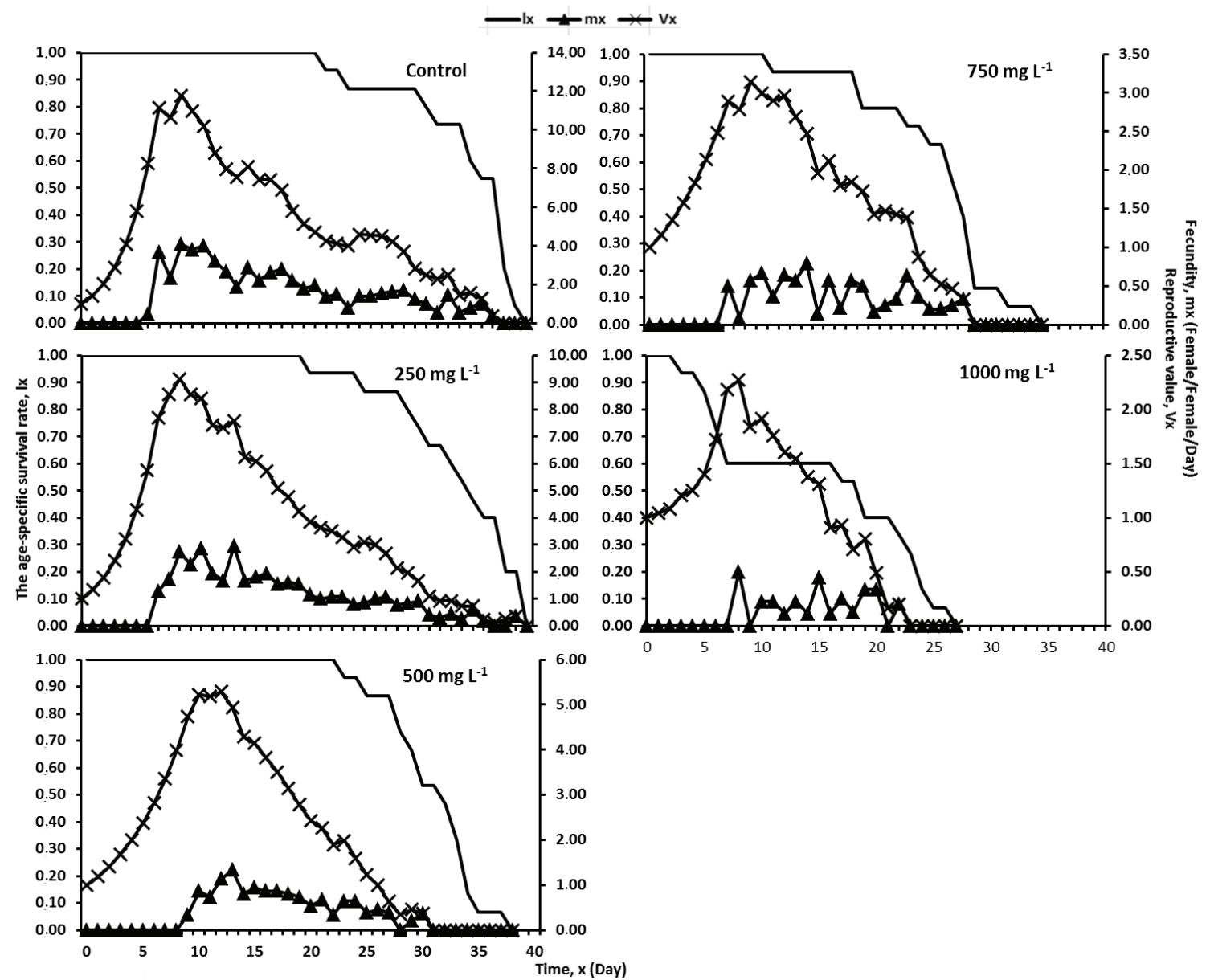

Figure 1- The age-specific survival rate $\left(\mathrm{l}_{\mathrm{x}}\right)$, fecundity rate $\left(\mathrm{m}_{\mathrm{x}}\right)$, and reproductive value $\left(\mathrm{V}_{\mathrm{x}}\right)$ of $M y z u s$ persicae exposed to neem at different concentrations

Based on the Weibull distribution models' parameters $b$ (scale) and c (shape), and coefficients of determination $\left(\mathrm{R}^{2}\right)$, it is possible to say that the individuals exposed to $1000 \mathrm{mg} \mathrm{L}^{-1}$ neem have the type 3 life curve, that is the type of decreasing population, and the age-specific survival rates $\left(l_{x}\right)$ of the individuals from other groups fit the type 1 life curve, that is the type of increasing population. Moreover, the Weibull distribution model for the age-specific survival rates $\left(l_{x}\right)$ did not show any compatibility to the data obtained from the individuals exposed to $1000 \mathrm{mg} \mathrm{L}^{-1}$. However, the Weibull distribution model was also found to be highly compatible with the data obtained from individuals in other groups (Figure 2). The very low coefficient of determination $\left(\mathrm{R}^{2}=0.4601\right)$ in the Weibull distribution model for the individuals exposed to $1000 \mathrm{mg} \mathrm{L}^{-1}$ is thought to be due to the high mortality rate and very short lifespan of adults in this group.

\subsection{Fecundity}

Mean daily and total number of offspring laid by females exposed to $250,500,750$ and $1000 \mathrm{mg} \mathrm{L}^{-1}$ 


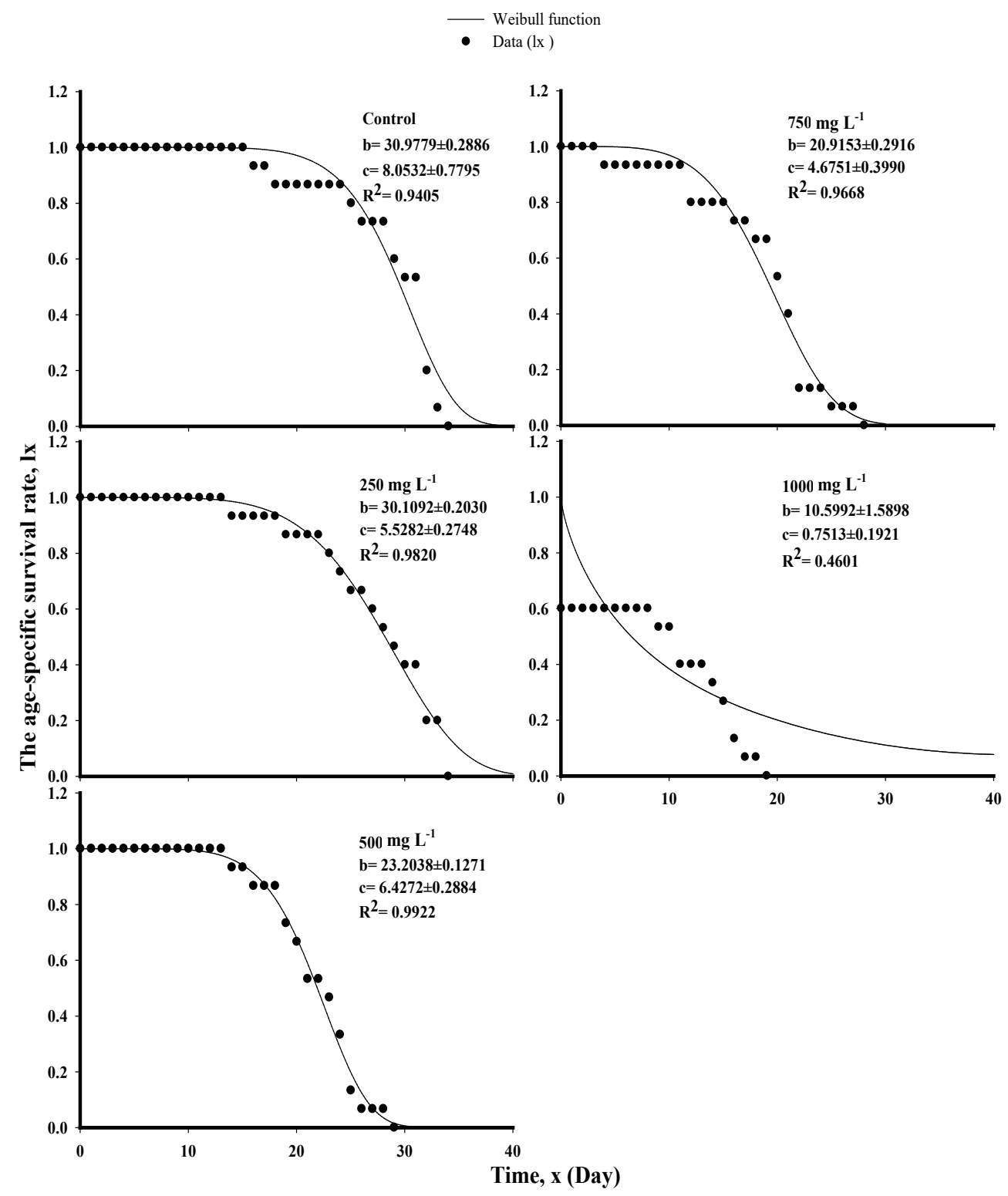

Figure 2- The Weibull distribution model for age-specific survival rates ( $\mathrm{l}_{\mathrm{x}}$ ) of individuals of Myzus persicae exposed to neem at different concentrations

neem concentrations are shown in Table 2. According to the obtained results, mean daily and total number of offspring laid by females of the pest decreased with the increasing concentrations of neem (Table 2).
Kraiss \& Cullen (2008) reported that the decrease of the fertility in $A$. glycines individuals exposed to neem-based insecticides was observed. Bhardwaj \& Ansari (2015) pointed out that neem, compared to the control, has a significant impact 
Table 2- Mean daily and total fecundity of Myzus persicae exposed to neem at different concentrations

\begin{tabular}{lccc}
\hline Concentrations & $N$ & $\begin{array}{c}\text { Mean daily fecundity }( \pm S E) \\
\text { (Offspring/female/day) }\end{array}$ & $\begin{array}{c}\text { Mean total fecundity }( \pm S E) \\
\text { (offspring/female) }\end{array}$ \\
\hline Control & 15 & $2.00 \pm 0.10 \mathrm{a}$ & $57.27 \pm 3.43 \mathrm{a}$ \\
$250 \mathrm{mg} \mathrm{L}^{-1}$ & 15 & $1.37 \pm 0.08 \mathrm{~b}$ & $37.93 \pm 1.98 \mathrm{~b}$ \\
$500 \mathrm{mg} \mathrm{L}^{-1}$ & 15 & $0.58 \pm 0.04 \mathrm{c}$ & $13.53 \pm 1.08 \mathrm{c}$ \\
$750 \mathrm{mg} \mathrm{L}^{-1}$ & 15 & $0.40 \pm 0.03 \mathrm{~d}$ & $7.71 \pm 0.72 \mathrm{~d}$ \\
$1000 \mathrm{mg} \mathrm{L}^{-1}$ & 15 & $0.24 \pm 0.02 \mathrm{e}$ & $3.67 \pm 0.50 \mathrm{e}$ \\
\hline
\end{tabular}

*, within same columns, the values ( \pm standard error) means sharing a letter are not significantly different from each other (Tukey's at $\mathrm{P}<0.05)$

on the fertility, hatchability and adult emergence rate of Earias vittella F. (Lepidoptera: Noctuidae). According to the results of this study, egg production of a female lepidopteran in its life was 300 eggs in the control group. The fecundity rate in the individuals exposed to neem at $0.70,1.10$, 1.50 and $1.90 \mathrm{mg}$ /individual was $229,188,166$ and 148 eggs/female, respectively. Hatching rate of these eggs, as compared to that of the control, were $88 \%, 75 \%, 63 \%$ and $46 \%$, respectively. The adult emergency rates were calculated as $80 \%, 70 \%$, $61 \%$ and $37 \%$, respectively in those studies. Besides that, A. indica was reported in a study by Silva et al (2013) to have an impact on the fecundity of C. capitata, too. It is announced in this study that the number of eggs laid by females at the $8^{\text {th }}$ day after the application of the extract derived from branches of $A$. indica in dichloromethane was reduced in proportion of approximately $80 \%$, and the hatching rate was decreased up to $30 \%$. The mean numbers of eggs oviposited daily by female of $C$. capitata were 12.7 eggs/female/day in the females exposed to the extract derived from branches of $A$. indica in dichloromethane and also, 21.5 eggs/female/ day in the females exposed to the extract derived from leaves of $A$. indica in methanol. Di Ilio et al (1999), in a study using 3 pairs of $C$. capitata adults per each replication, stated that the fecundity rate was 461.4 eggs/replicate in the control group, 279.7 eggs/replicate in the group applying $1 \mu \mathrm{L}$ neem, 98.2 eggs/replicate in the group applying $5 \mu \mathrm{L}$ neem and $1.2 \mathrm{eggs} /$ replicate in the group applying 10 $\mu \mathrm{L}$ neem. Khan et al (2007) applied a commercial preparation and leaf dust of neem on the adults of
Bactrocera cucurbitae (Coquillett) and B. dorsalis (Hendel) (Diptera: Tephritidae) to determine the effect on the longevity, fecundity and ovarian development of these pests. The results of this study showed that the degradation in the fecundity rates was due to the prevention of ovarian development and lifespans were decreased in a high proportion according to the control in both species.

The age-specific fecundity rates $\left(\mathrm{m}_{\mathrm{x}}\right)$ of apterous adult females on plants exposed to neem at different concentrations were described by the Enkegaard regression model (Figure 3).

The coefficient of determination $\left(\mathrm{R}^{2}\right)$ value was used as the suitability criteria of the Enkegaard regression model to obtained data (Kontodimas et al 2004). Enkegaard regression model of the data obtained from the individuals exposed to neem at $1000 \mathrm{mg} \mathrm{L}^{-1}$ concentration $\left(\mathrm{R}^{2}=0.2402\right)$ set out of the age-specific fecundity rate $\left(m_{x}\right)$ did not show coherence. It is observed that Enkegaard regression models were more compatibility for the data obtained from the other groups (Figure 3).

It is thought that this situation was due to low and variable fecundity rate and short lifespan of the individuals exposed to neem at $1000 \mathrm{mg} \mathrm{L}^{-1}$ concentration, as compared to that of other groups (Kontodimas et al 2007). In addition to this, the Enkegaard regression models showed that the fecundity rates decreased with the increasing application concentrations and times after applications. The highest fecundity rates in all experimental groups were observed in the first 7 days (Figure 3). 


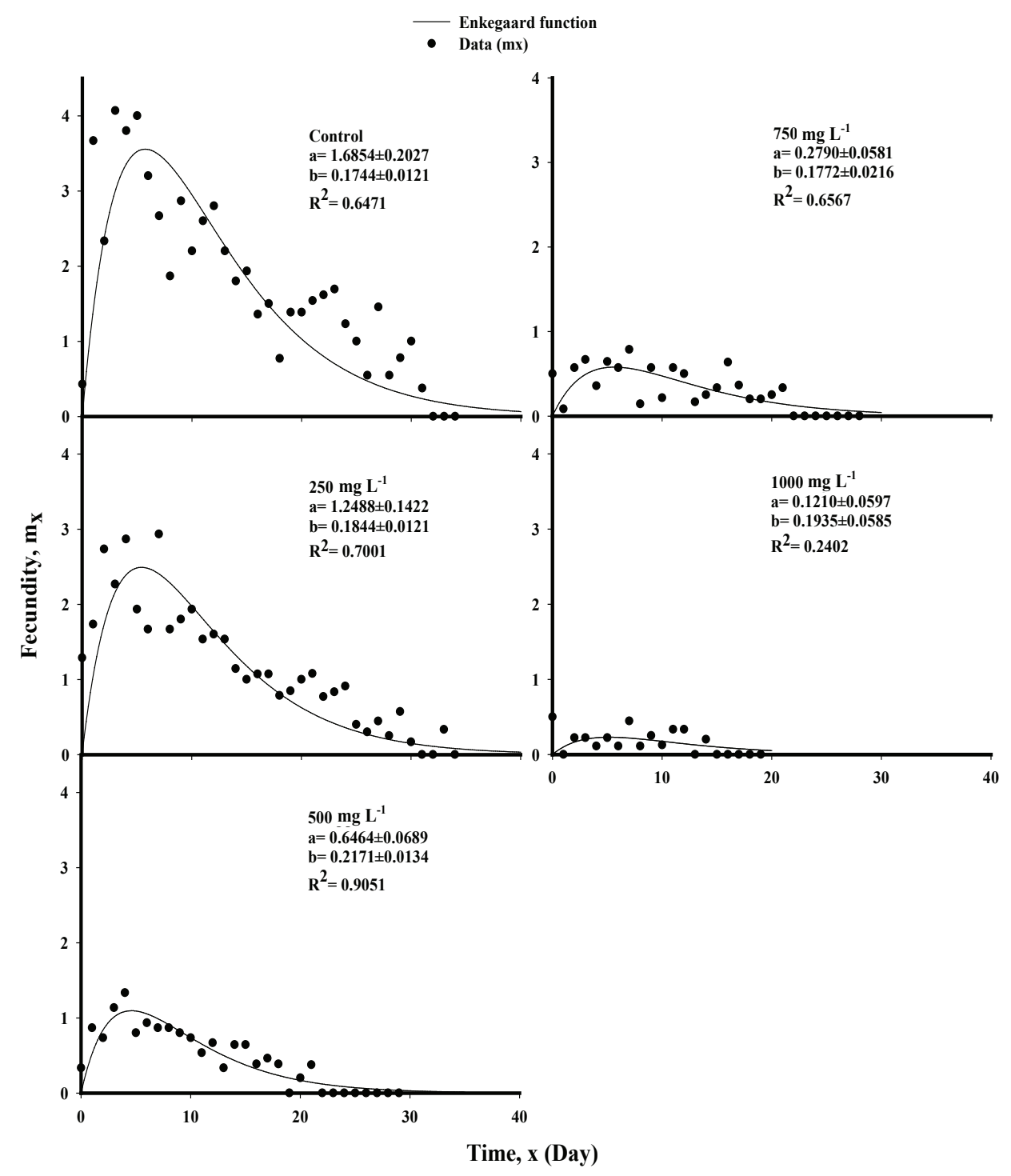

Figure 3- The Enkegaard regression models set out of the age-specific fecundity rate $\left(\mathrm{m}_{\mathrm{x}}\right)$ of the individuals of Myzus persicae exposed to neem at different concentrations

\subsection{Life table parameters}

Intrinsic rate of increase $\left(\mathrm{r}_{\mathrm{m}}\right)$, net reproductive rate $\left(\mathrm{R}_{0}\right)$, mean generation time $\left(\mathrm{T}_{0}\right)$, theoretical population-doubling time $\left(\mathrm{T}_{2}\right)$, gross reproduction rate (GRR) and finite rate of increase $(\lambda)$ values are seen in Table 3. Based on the results, it is possible to say that the individuals of M. persicae showed less breeding with increasing concentration of neem.

In a study performed by Barati et al (2013) on the effect of some botanical insecticides on Bemisia tabaci, net reproductive rate $\left(\mathrm{R}_{0}\right)$, intrinsic rate of increase $\left(\mathrm{r}_{\mathrm{m}}\right)$, mean generation time $\left(\mathrm{T}_{0}\right)$, theoretical 
Table 3- Life table parameters of Myzus persicae exposed to neem at different concentrations

\begin{tabular}{lrrrrr}
\hline Parameters & Control & $250 \mathrm{mg} \mathrm{L}^{-1}$ & $500 \mathrm{mg} \mathrm{L}^{-1}$ & $750 \mathrm{mg} \mathrm{L}^{-1}$ & $1000 \mathrm{mg} \mathrm{L}^{-1}$ \\
\hline Intrinsic rate of increase, $\mathrm{r}_{\mathrm{m}}$ & 0.352 & 0.291 & 0.173 & 0.152 & 0.039 \\
Net reproductive rate, $\mathrm{R}_{0}$ & 57.295 & 38.019 & 13.533 & 7.688 & 1.700 \\
Mean generation time, $\mathrm{T}_{0}$ & 11.503 & 12.249 & 15.086 & 13.446 & 13.715 \\
Gross reproduction rate, GRR & 60.60 & 40.46 & 14.02 & 8.91 & 3.19 \\
Theoretical population-doubling time, $\mathrm{T}_{2}$ & 1.970 & 2.381 & 4.014 & 4.569 & 17.915 \\
Finite rate of increase, $\lambda$ & 1.422 & 1.338 & 1.188 & 1.164 & 1.039 \\
$\mathrm{n}$ & 15 & 15 & 15 & 15 & 15 \\
\hline
\end{tabular}

population-doubling time $\left(\mathrm{T}_{2}\right)$ and finite rate of increase $(\lambda)$ values were determined as 8.23 female/ female, 0.090 female/female/day, 23.50 day, 7.56 day and 1.094 individual/female/day, respectively. Also it was declared that neem extracts have a high impact on the life table parameters of $B$. tabaci and they can be used in the scope of integrated pest management against this pest.

The statistical analysis practiced on the pseudo$r_{m j}$ values of the intrinsic rate of increases $\left(r_{m}\right)$ computed on the data obtained from the individuals of Myzus persicae exposed to different neem concentrations shows that the intrinsic rate of increases $\left(\mathrm{r}_{\mathrm{m}}\right)$ are located in the different statistical groups and the intrinsic rate of increases $\left(\mathrm{r}_{\mathrm{m}}\right)$ of the individuals were decreased with the increase in exposed neem concentration (Figure 4).

Meanwhile, a high correlation $\left[\mathrm{R}^{2} \mathrm{r}_{\mathrm{m} \text {, dose })}=0.97\right]$ was also found between the amount of concentration and the intrinsic rate of increase $\left(\mathrm{r}_{\mathrm{m}}\right)$ in consequence of the linear regression analysis performed on the data of the individuals exposed to different neem concentrations. As for that the formula $\left[\mathrm{r}_{\mathrm{m}}=-0.0766 *\right.$ Concentration +0.431$]$ given by this correlation $(\mathrm{P}<0.01)$, the increase of neem concentration applied to the root of pepper plants has led to a decrease in the intrinsic rate $\left(\mathrm{r}_{\mathrm{m}}\right)$ of M. persicae individuals (Figure 4).

A study by dos Santos et al (2004) exhibited the effect of neem at 23.8, 122.0, 410.0 and 1410.0 $\mathrm{mg} .100 \mathrm{~mL}^{-1}$ concentrations on the survival rate and fecundity of Aphis gossypii Glover (Hemiptera:

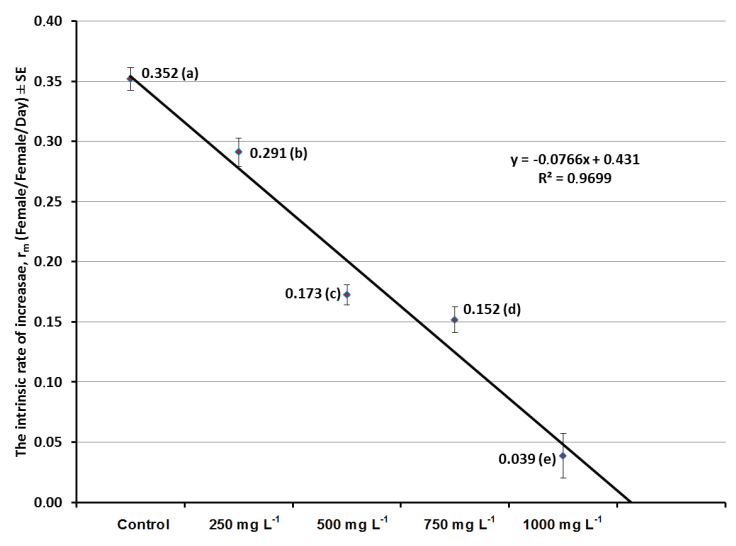

Figure 4- The intrinsic rate of increases $\left(r_{m}\right)$ of Myzus persicae exposed to neem at different concentrations and the correlation function between them $(\mathbf{P}<\mathbf{0 . 0 1})$. The values ( \pm standard error) means sharing a letter are not significantly different from each other (Tukey's at $\mathbf{P}<\mathbf{0 . 0 5}$ )

Aphididae). The results of this study indicated that nymphal mortalities at the highest two concentrations of neem reached up to $60 \%$ and $100 \%$. Net reproductive rate $\left(\mathrm{R}_{0}\right)$ of the individuals in the control group was defined as 35 female/ female/offspring. Also, this value was decreased with the increase of neem concentration and reduced down to zero.

\subsection{Root uptake of neem}

Neem taken up by pepper root can be transported in the vascular system systemic and translaminar (Pavela et al 2004; Souza \& Vendramim 2005; Hossain et al 
2008; Coelho Junior \& Deschamps 2014). Pavela et al (2004) performed soil application of neem at low concentrations to the root system of rape plant (Brassica napus subsp. napus) and explored its systemic effect on the mortality, development time, longevity and fecundity of Brevicoryne brassicae L. (Hemiptera: Aphididae). According to the results of the study, nymphal mortality of the pest, especially during the molting periods, was raised significantly with increasing concentrations. Neem has not any effect on the development time of nymphs. Longevity of adults and wasted time for feeding were decreased with increasing concentrations. It is also observed that fecundity rate of the aphid was reduced after the neem applications. Hossain et al (2008) examined the impact of neem applied to the root system of tomato plants on Liriomyza sativae (Diptera: Agromyzidae). In the study, 0.75, 1.50, 2.25 and $3.00 \mathrm{~g} \mathrm{~L}^{-1}$ concentrations of NeemAzal ${ }^{\circledR}-\mathrm{U}$ preparation were used. Fecundity and hatching rates were influenced slightly at all concentrations of neem, but larval mortality was affected significantly systemically by neem at $3.00 \mathrm{~g} \mathrm{~L}^{-1}$ concentration.

Meanwhile, it is know that neem has a phytotoxic effect on some plants (Walter 1999; Xuan et al 2004; Girish \& Shankara Bhat 2008; Soto et al 2010; Esparza-Díaz et al 2010; Saha et al 2011). Also in this present study, phytotoxic symptoms in the form of necrotic spots were seen on the leaves of plants exposed to 750 and $1000 \mathrm{mg} \mathrm{L}^{-1}$ concentrations of neem.

\section{Conclusions}

Based on the results of the present study, neem can be transported systemically, and soil application thereof has an effect on some biological characteristics of the aphid, Myzus persicae. Development times in the pre-adult stages were extended as exposed neem concentration was increased. Longevity, however, was decreased inversely with increasing concentration. Additionally, a decrease in the mean daily and total number of offspring laid by females of the pest was observed. On the other hand, azadirachtin- $\mathrm{A}$ as the most important compound of neem is highly sensitive to sunlight (Bajwa \&
Ahmad 2012) and as well as neem was identified to have adverse effect on some parasitoids (Lowery \& Isman 1995; Simmonds et al 2002; Lyons et al 2003; Saber et al 2004; Cóndor-Golec 2007; Abedi et al 2014). When considered from this point of view, applying of neem to the plant root zone was understood to provide also an advantage. This last point should also receive attention because it is important to have data in saving parasitoids against applications of neem. Finally, it can be said that applying of neem extracts systemically through plant root systems will provide an important advantage in controlling the sucking pests, like M. persicae, in agroecosystems performing integrated pest management.

\begin{tabular}{|ll|}
\hline \multicolumn{2}{|c|}{ Abbreviations and Symbols } \\
\hline$a, b, c$ & Model coefficients \\
$l_{\mathrm{x}}$ & The age-specific survival rate \\
$\mathrm{m}_{\mathrm{x}}$ & Fecundity rate \\
$\mathrm{V}_{\mathrm{x}}$ & Reproductive value \\
$\mathrm{r}_{\mathrm{m}}$ & Intrinsic rate of increase \\
$\mathrm{R}_{0}$ & Net reproductive rate \\
$\mathrm{T}_{0}$ & Mean generation time \\
$\mathrm{T}_{2}$ & Theoretical population-doubling time \\
$\mathrm{GRR}$ & Gross reproduction rate \\
$\lambda$ & Finite rate of increase \\
$\mathrm{S}_{\mathrm{p}}(\mathrm{x})$ & The probability of survival at $\mathrm{x}$ age \\
$\mathrm{F}_{(\mathrm{x})}$ & The probability of fecundity at $\mathrm{x}$ age \\
\hline
\end{tabular}

\section{References}

Abedi Z, Saber M, Gharekhani G, Mehrvar A \& Kamita S G (2014). Lethal and Sublethal Effects of Azadirachtin and Cypermethrin on Habrobracon hebetor (Hymenoptera: Braconidae). Journal of Economic Entomology 107(2): 638-645

Ascher K R S (1993). Nonconventional Insecticidal Effects of Pesticides Available From the Neem Tree, Azadirachta indica. Archives of Insect Biochemistry and Physiology 22: 433-449

Bajwa A A \& Ahmad A (2012). Potential applications of neem based products as biopesticides. The Health 3(4): 116-120

Barati R, Golmohammadi G, Ghajarie H, Zarabi M \& Mansouri R (2013). The effects of some botanical insecticides and pymetrozine on life table parameters of silver leaf whitefly Bemisia tabaci 
Gennadius (Hemiptera: Aleyrodidae). Pesticides and Phytomedicine (Belgrade) 28(1): 47-55

Bhardwaj A K \& Ansari B A(2015). Effect of Nimbecidine and Neemazal on the developmental programming of cotton pest, Earias vittella. Journal of Entomology and Zoology Studies 3(1): 38-42

Birch L C (1948). The intrinsic rate of natural increase of an insect population. Journal of Animal Ecology 17: $15-26$

Cloquemin G, Hérold D \& Geny A (1990). La résistance des pucerons aux aphicides. Phytoma 423(12): 60-63

Cloyd R A \& Sadof C S (1998). Aphids: Biology and management. Floriculture Indiana 12(2): 3-7

Coelho Junior A \& Deschamps F C (2014). Systemic and translaminar action of neem oil for the control of Tuta absoluta (Meyrick) (Lep.: Gelechiidae) in tomato. Arquivos do Instituto Biológico São Paulo 81(2): 140-144

Cóndor-Golec A F (2007). Effect of neem (Azadirachta indica A. Juss) insecticides on parasitoids. Revista Peruana de Biología, 14(1): 69-74

Deevey E S (1947). Life Tables for natural populations of animals. The Quarterly Review of Biology 22(4): 283-314

Di Ilio V, Cristofaro M, Marchini D, Nobili P \& Dallai R (1999). Effects of a neem compound on the fecundity and longevity of Ceratitis capitata (Diptera: Tephritidae). Journal of Economic Entomology 92(1): 76-82

dos Santos T M, Costa N P, Torres A L \& Boiça Júnior A L (2004). Effect of neem extract on the cotton aphid. Pesquisa Agropecuária Brasileira 39(11): 1071-1076

Enkegaard A (1993). The poinsettia strain of the cotton whitefly, Bemisia tabaci (Hom.; Aleyrodidae), biological and demographic parameters on poinsettia (Euphorbia pulcherrima) in relation to temperature. Bulletin of Entomological Research 83: 535-546

Esparza-Díaz G, López-Collado J, Villanueva-Jiménez J A, Osorio-Acosta F, Otero-Colina G \& CamachoDíaz E (2010). Azadirachtin concentration, insecticide efficacy and phytotoxicity of four neem Azadirachta indica A. Juss. extracts. Agrociencia 44(7): 821-833

Girish K \& Shankara Bhat S (2008). Neem - a green treasure. Electronic Journal of Biology 4(3): 102-111

Hansen D L, Brødsgaard H F \& Enkegaard A (1999). Life table characteristics of Macrolophus caliginosus preying upon Tetranychus urticae. Entomologia Experimentalis et Applicata 93: 269-275

Hossain M B, Poehling H-M, Thöming G \& Borgemeister C (2008). Effects of soil application of neem (NeemAzal $\left.{ }^{\circledR}-\mathrm{U}\right)$ on different life stages of Liriomyza sativae (Diptera: Agromyzidae) on tomato in the humid tropics. Journal of Plant Diseases and Protection 115(2): 80-87

Imura O (1987). Demographic attributes of Tribolium freemani Hinton (Coleoptera: Tenebrionidae). Applied Entomology and Zoology 22(4): 449-455

Isman M B (1997). Neem and other botanical insecticides: barriers to commercialization. Phytoparasitica 25(4): 339-344

Kairo M T K \& Murphy S T (1995). The life history of Rodolia iceryae Janson (Coleoptera: Coccinellidae) and the potential for use in innoculative releases against Icerya pattersoni Newstead (Homoptera: Margarodidae) on coffee. Journal of Applied Entomology 119: 487-491

Khan M, Hossain M A \& Islam M S (2007). Effects of neem leaf dust and a commercial formulation of a neem compound on the longevity, fecundity and ovarian development of the melon fly, Bactrocera cucurbitae (Coquillett) and Oriental fruit fly, Bactrocera dorsalis (Hendel) (Diptera: Tephritidae). Pakistan Journal of Biological Science 10(20): 3656-3661

Kontodimas D C, Eliopoulos P A, Stathas G J \& Economou L P (2004). Comparative temperaturedependent development of Nephus includens (Kirsch) and Nephus bisignatus (Boheman) (Coleoptera: Coccinellidae), preying on Planococcus citri (Risso) (Homoptera: Pseudococcidae): Evaluation of a linear and various non-linear models using specific criteria. Environmental Entomology 33: 1-11

Kontodimas D C, Milonas P G, Stathas G J, Economou L P \& Kavallieratos N G (2007). Life table parameters of the pseudococcid predators Nephus includens and Nephus bisignatus (Coleoptera: Coccinelidae). European Journal of Entomology 104: 407-415

Kraiss H \& Cullen E M (2008). Insect growth regulator effects of azadirachtin and neem oil on survivorship, development and fecundity of Aphis glycines (Homoptera: Aphididae) and its predator, Harmonia axyridis (Coleoptera: Coccinellidae). Pest Management Science 64: 660-668 
Lowery D T \& Isman M B (1995). Toxicity of neem to natural enemies of aphids. Phytoparasitica 23(4): 297-306

Lyons D B, Helson B V, Bourchier R S, Jones G C \& McFarlane J W (2003). Effects of azadirachtin-based insecticides on the egg parasitoid Trichogramma minutum (Hymenoptera: Trichogrammatidae). The Canadian Entomologist 135(5): 685-695

Meyer J S, Ingersoll C G, McDonald L L \& Boyce M S (1986). Estimating uncertainty in population growth rates: Jackknife vs. Bootstrap techniques. Ecology 67: 1156-1166

Özgökçe M S \& Atlıhan R (2004). Biological features and life table parameters of mealy plum aphid, Hyalopterus pruni on different apricot cultivars. Phytoparasitica 33(1): 7-14

Özgökçe M S \& Karaca İ (2010). Lifetable: Fundamental Principles and Applications. 1. Workshop of Entomological Society of Turkey, Ecology Working Group, Isparta,Turkey.

Pavela R, Barnet M \& Kocourek F (2004). Effect of azadirachtin applied systemically through roots of plants on the mortality, development and fecundity of the cabbage aphid (Brevicoryne brassicae). Phytoparasitica 32(3): 286-294

Pinder J E, Wiener J G \& Smith M H (1978). The Weibull distribution: a new method of summarizing survivorship data. Ecology 59: 175-179

Saber M, Hejazi M J \& Hassan S A (2004). Effects of Azadirachtin/Neemazal on different stages and adult life table parameters of Trichogramma cacoeciae. Journal of Economic Entomology 97(3): 905-910

Saha S, Walia S \& Parmar B S (2011). Exploring the diversity of neem bioactives as eco-benign pesticides: a reappraisal. Toxicological \& Environmental Chemistry 93(8): 1508-1546

Silva M A, Bezerra-Silva G C D, Vendramim J D \& Mastrangelo T (2013). Sublethal effect of neem extract on Mediterranean fruit fly adults. Revista Brasileira de Fruticultura 35(1): 93-101

Simmonds M S J, Manlove J D, Blaney W M \& Khambay B P S (2002). Effects of selected botanical insecticides on the behavior and mortality of the glasshouse whitefly Trialeurodes vaporariorum and the parasitoid Encarsia formosa. Entomologia Experimentalis et Applicata 102(1): 39-47

Soto A, Venzon M, Oliveira R M, Oliveira H G \& Pallini A (2010). Alternative control of Tetranychus evansi Baker \& Pritchard (Acari: Tetranychidae) on tomato plants grown in greenhouses. Neotropical Entomology 39(4): 638-644

Souza A P de \& Vendramim J D (2005). Translaminar, systemic and topical effects of aqueous extract of neem seed on Bemisia tabaci (Genn.) Biotype B on tomato plants. Neotropical Entomology 34(1): 83-87

Tingle C C D \& Copland M J W (1989). Progeny production and adult longevity of the mealybug parasitoids Anagyrus pseudococci, Leptomastix dactylopii and Leptomastidea abnormis (Hymenoptera: Encyrtidae) in relation to temperature. Entomophaga 34: 111-120

Tukey J W (1949). Comparing individual means in the analyses of variance. Biometrics 5: 99-114

Ujváry I (2001). Pest Control Agents from Natural Products. In: R I Krieger (Ed), Handbook of pesticide toxicology, 23 ${ }^{\text {rd }}$ edition, Academic Press, San Diego, pp. $109-179$

Uygun N, Ulusoy M R, Karaca İ \& Satar S (2013). Meyve ve Bağ Zararlıları. Akademisyen Kitabevi, Ankara

Xuan T D, Eiji T, Hiroyuki T, Mitsuhiro M, Khanh T D \& Chung I-M (2004). Evaluation on phytotoxicity of neem (Azadirachta indica A. Juss) to crops and weeds. Crop Protection 23: 335-345

Waghmare J T, Ware A M \& Momin S A (2007). Neem oil as pesticide. Journal of Dispersion Science and Technology 28(2): 323-328

Walter J F (1999). Commercial experience with neem products. In: F R Hall \& J J Menn (Eds), Method in Biotechnology 5: Biopesticides, Humana Press, Totowa, New Jersey, pp. 155-170

Wang J J, Tsai J H, Zhao Z M \& Li L S (2000). Development and reproduction of the psocid Liposcelis bostrychophila (Psocoptera: Liposcelididae) as a function of temperature. Annals of the Entomological Society of America 93: 261-270 